\title{
IMPROVEMENT OF THE TECHNOLOGY OF EARTHWORKS IN MEGACITIES
}

\author{
Elena Kurakina ${ }^{1}$, Sergey Evtyukov ${ }^{2}$, Anna Shimanova ${ }^{3}$ \\ 1,2,3 Saint Petersburg State University of Architecture and Civil Engineering \\ Vtoraja Krasnoarmejskaja ul. 4, St. Petersburg, Russia \\ 1elvl_86@mail.ru
}

\begin{abstract}
The study substantiates the need to improve the existing technology of earthworks in megacities. The use of alternative types of over-ground transport technological machines would change the management and process control algorithm, increase performance efficiency and quality of operations, reduce costs for procedure implementation. Shortcomings of the existing technology of earthworks in the space-limited urban environment are analyzed. An implementation procedure for the existing technology to carry out operations with the use of transport technological machines and auxiliary equipment is presented.

The study also substantiates the need for practical application of such alternative type of over-ground transport technological machines as the vacuum excavator during earthworks. A set of transport technological machines for earthworks based on the improved technology with the use of the vacuum excavator was formed; space-limited conditions of megacities were taken into account.
\end{abstract}

\section{Keywords}

Construction machinery, vacuum excavator, construction machinery operation, earthworks and road works, megacity.

\section{Introduction}

The relevance of the issue is determined, firstly, by technological advances and the need to improve the machinery and equipment used in the road construction industry, in particular, in earthworks during utilities construction. Earthworks include reconstruction, maintenance, current and major repair of underground utilities (gas and water pipelines, laying of power cables, etc.). Secondly, all process operations can be improved with the available modern mobile machinery and equipment designed for earthworks during utilities construction. Thirdly, the existing process technologies imply the risk of utilities damaging with heavy machinery, e.g. excavators. To avoid such damaging, all works are performed manually, reducing mechanization. All these aspects are "included" in works performed in the space-limited urban environment, which is due to inaccessibility of actual working areas. Practical work requires operation quality improvement, risk reduction with regard to utilities damaging caused by the introduction of a universal transport technological machine - the vacuum excavator — into earthworks. This sphere was partially investigated by Volkov S. A. (Volkov and Evtyukov, 2008) and Beletskiy B. F. (Beletskiy and Bulgakova, 2012); however, taking into account the recent application of the vacuum excavator in the North-Western region, we can state that the issue has not been studied in full and is not considered in researches performed by leading experts and scientists of the industry. Therefore, studies on the improvement of earthworks technologies are necessary and relevant.

The relevance of the study is determined by the need to develop a flow chart to perform earthworks with the vacuum excavator on different types of road surfacing, taking into account the space-limited megacity environment and various temperatures.

\section{Subject, objectives and methods}

The subject of the study is the technology of earthworks in the space-limited megacity environment.

The study objectives are the following:

- analysis of shortcomings related to the existing technology of earthworks in the space-limited urban environment;

- substantiation of the need for practical application of an alternative type of over-ground transport technological machines (OTTMs) during earthworks;

- formation of a set of OTTMs for earthworks in various megacity conditions. 
Table 1. Set of mechanized OTTMs for earthworks based on the existing technology used in megacities

\begin{tabular}{|c|c|c|c|c|c|c|c|c|c|c|c|c|}
\hline \multirow{3}{*}{ 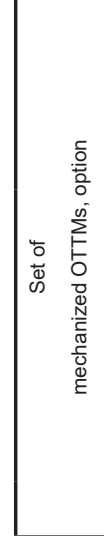 } & \multicolumn{2}{|l|}{ 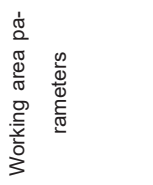 } & \multicolumn{10}{|c|}{ 言 } \\
\hline & \multirow[t]{2}{*}{ 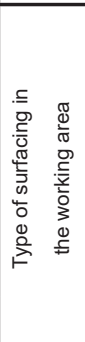 } & \multirow[t]{2}{*}{ 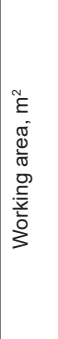 } & 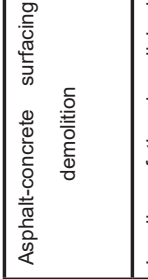 & 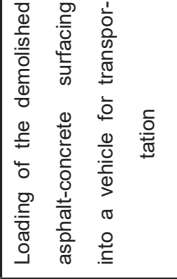 & 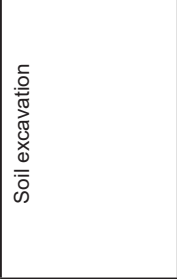 & 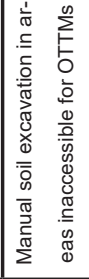 & 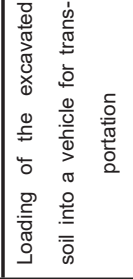 & 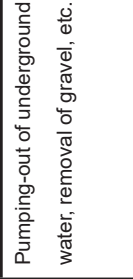 & 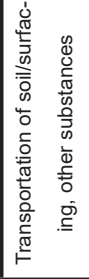 & 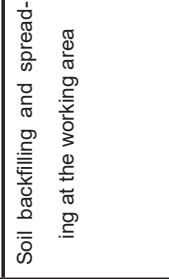 & 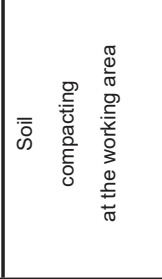 & 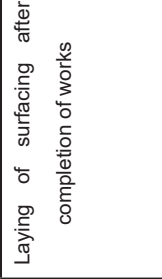 \\
\hline & & & - & N & m & o & ๑ & 0 & $\wedge$ & $\infty$ & $\sigma$ & $\stackrel{\circ}{\circ}$ \\
\hline - & 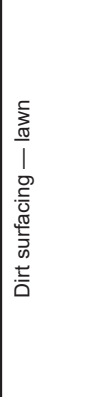 & 1 & 1 & 1 & 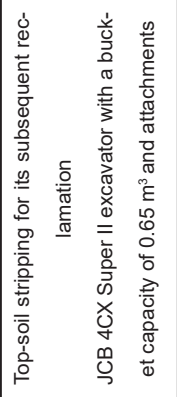 & 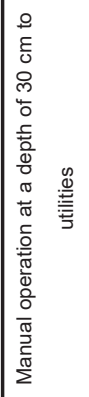 & 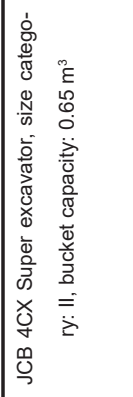 & 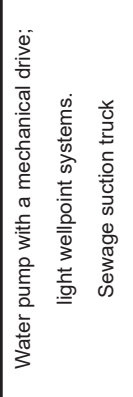 & 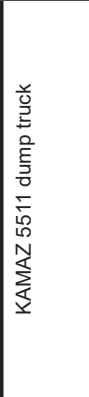 & 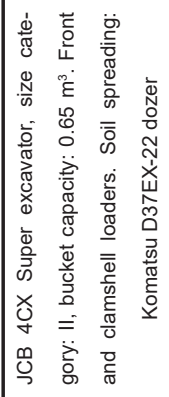 & 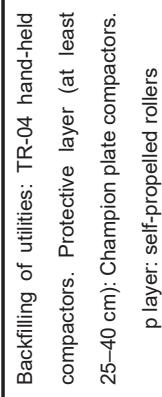 & 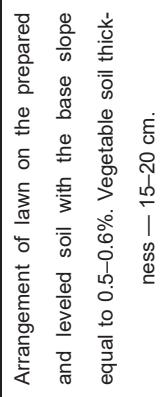 \\
\hline$N$ & 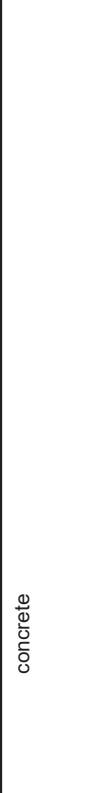 & 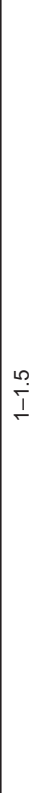 & 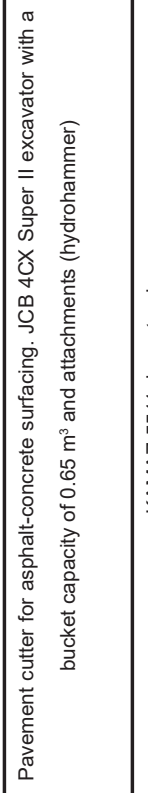 & 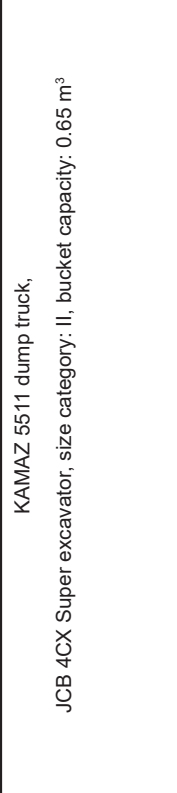 & 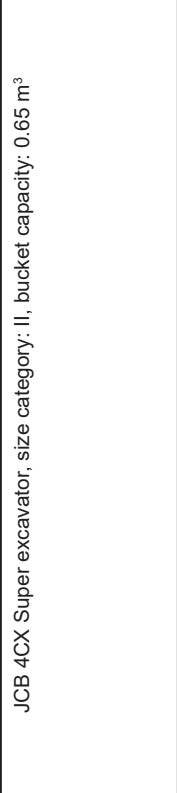 & 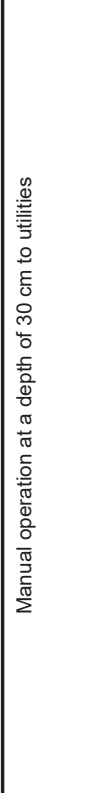 & 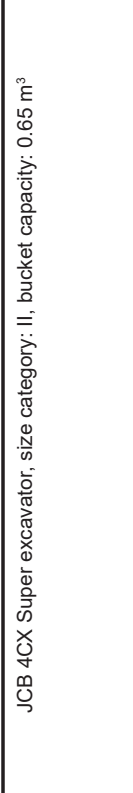 & 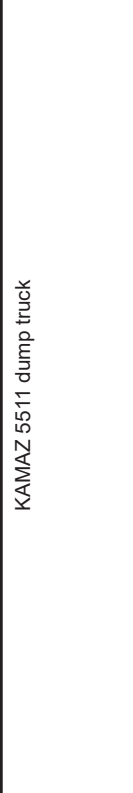 & 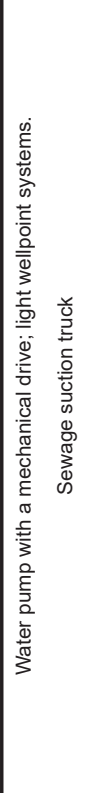 & 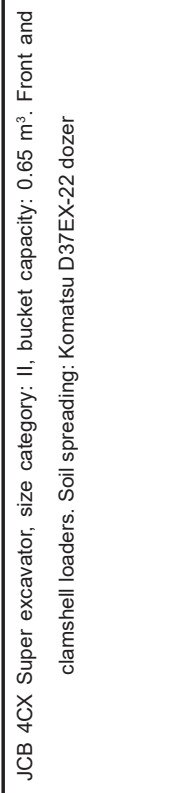 & 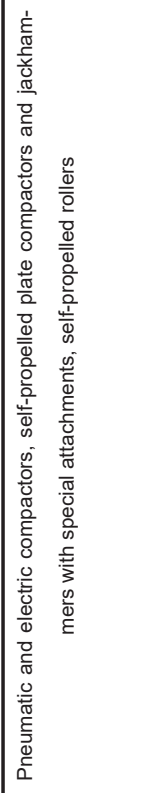 & 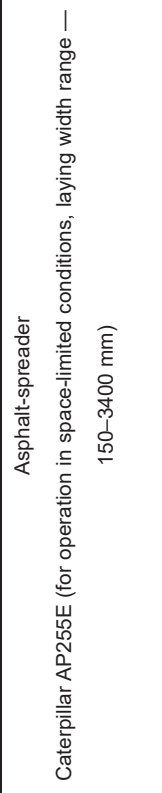 \\
\hline$m$ & & 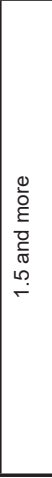 & 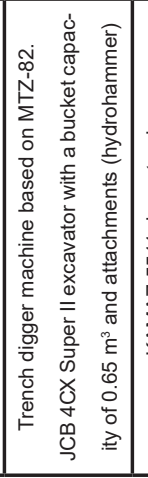 & 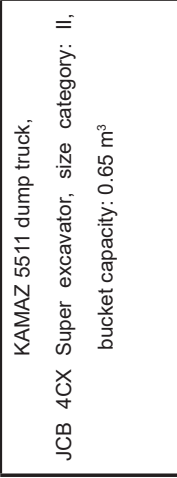 & 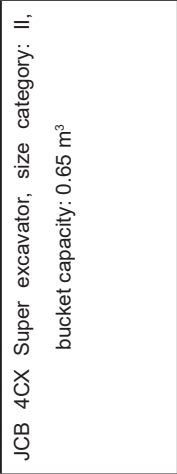 & 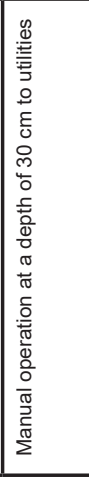 & 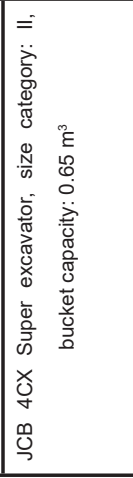 & 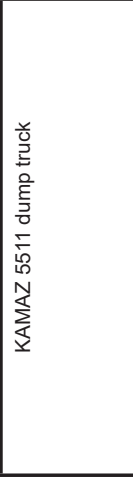 & 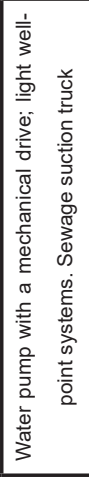 & 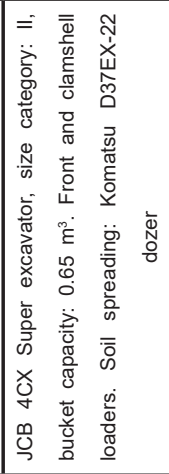 & 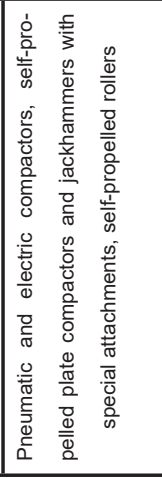 & 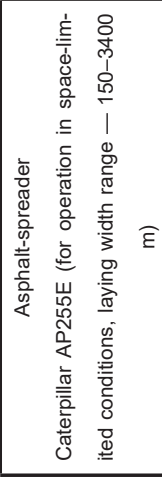 \\
\hline
\end{tabular}


Architecture and Engineering Volume 2 Issue 4

Table 2. Set of mechanized OTTMs for earthworks based on the improved technology used in megacities

\begin{tabular}{|c|c|c|c|c|c|c|c|c|c|c|c|c|}
\hline \multirow{3}{*}{ 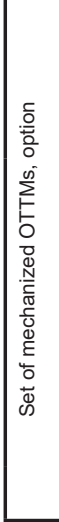 } & \multicolumn{2}{|l|}{ 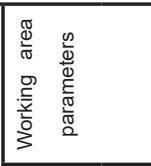 } & \multicolumn{10}{|l|}{ 产 } \\
\hline & \multirow[t]{2}{*}{ 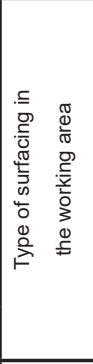 } & \multirow[t]{2}{*}{ 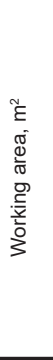 } & 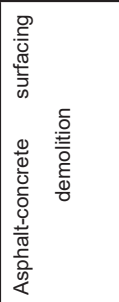 & 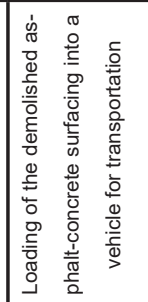 & 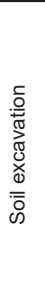 & 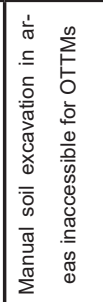 & 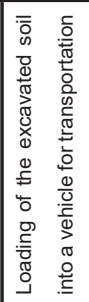 & 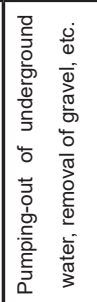 & 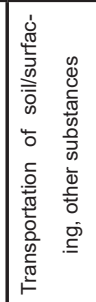 & 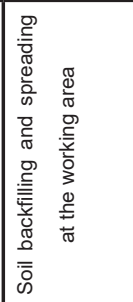 & 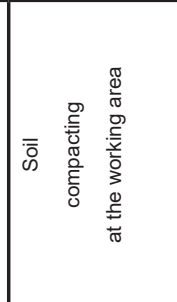 & 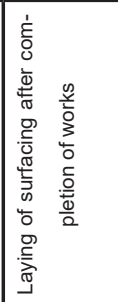 \\
\hline & & & - & $\sim$ & $m$ & ब & $\infty$ & 0 & r & $\infty$ & 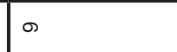 & $\div$ \\
\hline- & 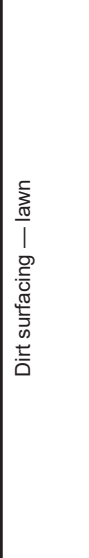 & 1 & 1 & 1 & & & 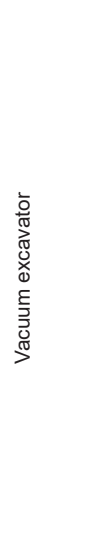 & & & 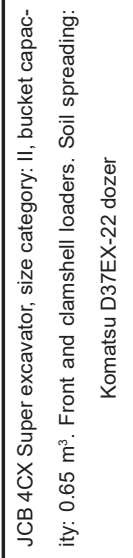 & 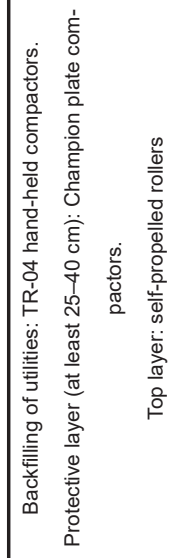 & 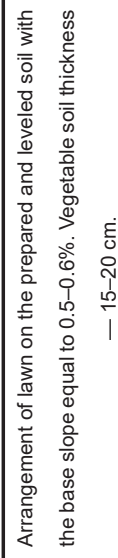 \\
\hline$\sim$ & 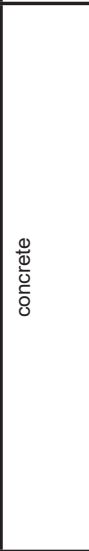 & | & 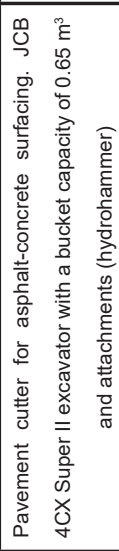 & & & 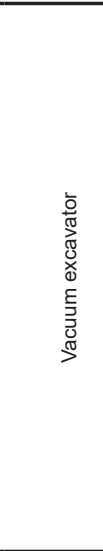 & & & & 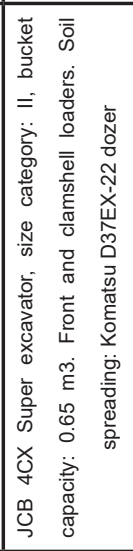 & 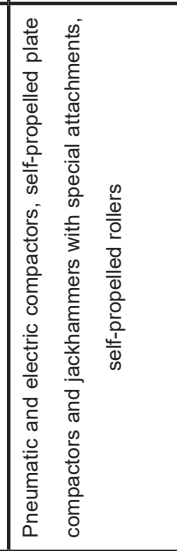 & 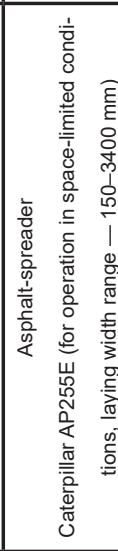 \\
\hline$m$ & & 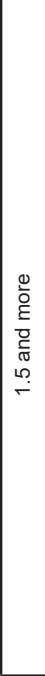 & 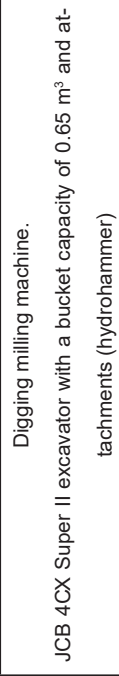 & & & 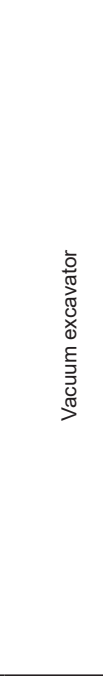 & & & & 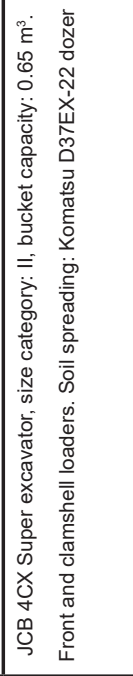 & 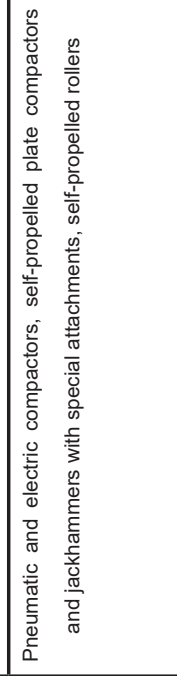 & 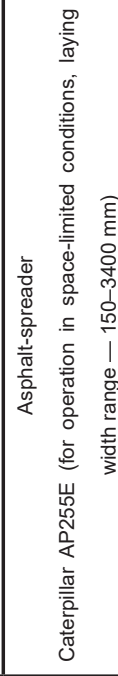 \\
\hline
\end{tabular}


Methods to accomplish the set objectives include methods to analyze solutions to problems of large-scale construction mechanization, processes of practical management and actual performance of works, technical and operating characteristics and properties of OTTMs.

\section{Results and discussion}

Technological advances contribute to the continuous improvement of design properties of OTTMs and their mechanisms to perform a wide range of activities in various fields, in particular, the road construction industry which includes not only the construction of facilities, buildings and structures, but also earthworks. The main types of earthworks and road works are the following: soil excavation, soil filling, soil transportation and movement, excavation of frozen soils, demolition and resurfacing of asphalt-concrete pavement, opening-up and repair of underground utilities, preparation of road mixtures, bitumen transportation and distribution, laying, distribution and compaction of the asphalt-concrete mixture.

The earthworks technology is based on the developed and approved design documentation and a set of mechanized OTTMs. Taking into account the specifics of the labor-intensive operations performed, an analysis of the technical and economic parameters that determine the most efficient combination of machines with regard to cost and labor input is made (Kurakina, 2016a, 2016b; Evtyukov et al., 2016; 2017). Reconstruction, repair and improvement of the utility network are considered to be in demand among other types of earthworks. This process is rather labor-intensive in the space-limited urban environment and requires a specific approach to the improvement of its implementation technology. The shortcomings of the existing technology of earthworks in megacities are the following (Evtyukov et al., 2017; Kurakina, 2017):

- risk of utilities damaging (heat and gas pipelines, power transmission lines);

- manual soil excavation in areas inaccessible for OTTMs;

- increase in the number of OTTMs in the set, increase in the working area for the performance of works involving asphalt-concrete surfacing;

- increase in the area of lawn damage during OTTM operation;

- reduction of lanes (or temporary lane closure) during works on the driveway;

- complexity of processes during the performance of works at freezing temperatures;

- decrease in environmental safety.

Practical implementation of activities limits operation of OTTMs during the reconstruction, repair and improvement of the utility network. Safety requirements to gas supply systems do not allow for the operation of percussive mechanisms for soil loosening at a distance less than $3 \mathrm{~m}$ from a gas pipeline. Driving of piles shall not be carried out at a distance less than $30 \mathrm{~m}$ from a gas pipeline (in case of compliance with additional safety measures, such distance can be reduced to $10 \mathrm{~m}$ ).
Earthworks at a distance less than $3 \mathrm{~m}$ and at a depth of $30 \mathrm{~cm}$ to utilities imply manual soil excavation. Winter operations are characterized by complicated processes, e.g. excavation of frozen soil due to the impossibility to use certain types of OTTMs, which leads to the decrease in their performance rate and accelerated deterioration of working parts and equipment, and possible compacting of frozen soil.

The increase in the number of OTTM units leads to the increase in the occupied working area, as well as to the increase in the number of maintenance specialists. All these factors contribute to the decrease in the efficiency of earthworks and labor management, increase in costs for the implementation of the earthworks technology and OTTM operation (Kurakina, 2017; Kurakina et al., 2017; Kurakina and Tsymbal, 2017; Kurakina et al., 2017).

The application of an alternative type of OTTMs - the vacuum excavator - for earthworks is conditioned by the need to eliminate all existing shortcomings. The rules of earthworks and urban landscaping are regulated by individual legal documents of the Ministry of Regional Construction. Options for the performance of earthworks at various stages according to the existing technology are presented in Table 1.

Subsequent measures on the reconstruction, repair and improvement of the utility network are specified for cases when underground water, silt, gravel or other substances are present at positive temperatures or have been removed.

set of mechanized OTTMs with a vacuum excavator was specified to improve the technology of earthworks in megacities (Table 2).

The improvement of the technology of earthworks in megacities is determined by the following factors:

- formation of a set of OTTMs and auxiliary equipment for earthworks;

- changing of the process algorithm.

Firstly, the formation of the necessary number of units of transport technological machines and auxiliary equipment contributes to obtaining higher performance and reliability rates, as well as values of environmental and engineering aspects. The introduction of a modern multifunctional OTTM - the vacuum excavator - would eliminate shortcomings in the arrangement and performance of earthworks, and improve their quality and performance rate.

Technical capabilities of the vacuum excavator include removal of dirt, sand, clay, gravel, damp soil, dust, water, crushed stones, debris and stones, as well as liquids and gases, large and heavy objects with a weight of up to 40 $\mathrm{kg}$ and a diameter of up to $250 \mathrm{~mm}$. Secondly, the changing of the process algorithm is aimed at the replacement of several OTTMs (the excavator, the sewage suction truck and the dump truck), as well as complete elimination of manual operations.

According to the overall assessment of over-ground transport technological machines (Volkov and Evtyukov, 2008; Repin and Chmil, 2012), their efficiency involves 


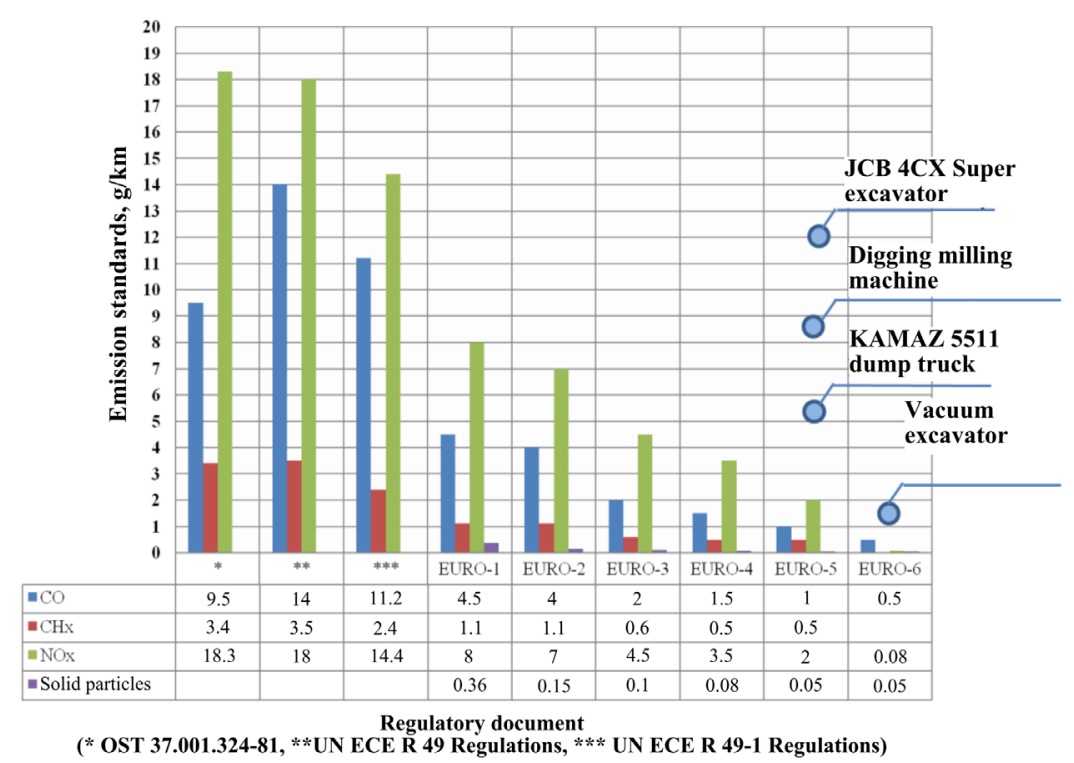

Figure 1. Histogram of emissions of harmful substances in accordance with the international standards upon OTTM operation

the reduction of fuel consumption and period of work performance, increase in the performance rate, reduction of the lane closure area in the urban environment, elimination of manual operations and risks of damage to utilities (Erokhov, 2013). An important condition for selection of OTTMs for the fleet of vehicles to be used in a megacity is compliance with the international standards for environmental safety.

Figure 1 shows a histogram of emissions of harmful substances in accordance with the international standards and compliance of the OTTMs most often used during earthworks with those standards.

An important factor for the technology improvement is to avoid downtimes and lost time during a shift, reduce costs as well as the number of OTTM units in the mechanized set and the number of maintenance specialists. When comparing the existing earthworks technology with the alternative technology, it is important to compare fuel consumption in operating OTTMs. For example, when performing operation 7 (Tables 1,2) taking into account the type of excavated material (soil or asphalt-concrete surfacing) and other substances (if any), the fuel consumption during operation of the vacuum excavator is less by $1 / 3$ than the fuel consumption of the dump truck and the sewage suction truck (Table 3 ). During operations from 3 (2) to 6 , the fuel consumption of the vacuum excavator is almost the same as the fuel consumption of the excavator with the sewage suction truck (Table 3). With account for the basic specifications of OTTMs for fuel consumption, operational parameters for the stated types of OTTMs were obtained with regard to the consumption rates for fuels and lubricants in motor vehicles (Ministry of Transport of the RF, 2015).
Table 3. Operational parameters with regard to OTTM fuel consumption

\begin{tabular}{|c|c|c|}
\hline \multirow{2}{*}{ OTTM } & \multicolumn{2}{|c|}{ Fuel consumption } \\
\cline { 2 - 3 } & $\mathrm{I} / \mathrm{h}$ & $\mathrm{l} / 100 \mathrm{~km}$ \\
\hline Vacuum excavator & 31 & 59.6 \\
\hline $\begin{array}{c}\text { JCB excavator with at- } \\
\text { tachments }\end{array}$ & 14.3 & - \\
\hline KAMAZ $\begin{array}{c}5511 \text { dump } \\
\text { truck }\end{array}$ & - & 43.4 \\
\hline Sewage suction truck & 14.0 & 41.4 \\
\hline
\end{tabular}

An advantage of the vacuum excavator over three OTTMs used during earthworks is in overall dimensions; its application allows reducing the area of damage to lawns and the lane closure area.

\section{Conclusion}

The improvement of the earthworks technology with the application of the vacuum excavator is relevant and necessary to improve the quality of the management and process control procedure, especially in space-limited conditions of megacities, as well as to increase the performance rate. The alternative technology compared to the existing one (or alternative to the existing technology) allows reducing the number of OTTM units in the mechanized set and the number of maintenance specialists, eliminating manual operations, improving quality and reducing the period of work performance, reducing risks of damage to utilities due to the knuckle boom of the vacuum excavator, and reducing fuel consumption by almost $30 \%$ of the total volume. 


\section{References}

Beletskiy, B.F., Bulgakova I.G. (2012). Stroitelnaia tekhnika i oborudovanie [Construction machinery and equipment], 3rd edition. Saint Petersburg: Lan Publishing House, p.608. (in Russian)

Erokhov, V.I. (2013). Toksichnost sovremennykh avtomobilei (metody i sredstva snizheniia vrednykh vybrosov $v$ atmosferu) [Toxicity of modern vehicles (methods and means of reducing harmful emissions into the atmosphere)]. Moscow: Infra-M, p.448. (in Russian)

Evtyukov, S.A., Evtyukov, S.S., Chudakov, A.V., Kurakina, E.V. (2017). Over-ground transport technological machines and complexes // Textbook for higher educational institutions. Saint Petersburg: Petropolis Publishing House, p.644. (in Russian)

Evtyukov, S.S., Chudakov, A.V., Kurakina E.V. (2016). Nazemnye transportno-tekhnologicheskie mashiny [Over-ground transport technological machines]. Saint Petersburg: LLC Petropolis Publishing House, p.504. (in Russian)

Kurakina, E.V. (2016a). Effektivnost ispolzovaniia nazemnykh transportno-tekhnologicheskikh mashin [Efficiency of use of overground transport technological machines]. Vestnik grazhdanskikh inzhenerov [Bulletin of Civil Engineers], 3 (56), pp. 203-208. (in Russian)

Kurakina, E.V. (2016b). Tekhnicheskaia ekspluatatciia nazemnykh transportno-tekhnologicheskikh mashin [Operation and maintenance of over-ground transport technological machines]. In: Proceedings of the 69th Scientific and Practical Conference of Students, PhD Students and Young Scientists "Challenging Issues of Modern Construction". Saint Petersburg: (in Russian)

Kurakina, E.V. (2017). Povyshenie effektivnosti nazemnykh transportno-tekhnologicheskikh mashin v zimnikh usloviiakh [Improving the efficiency of land transport and technological machines in winter conditions]. Vestnik grazhdanskikh inzhenerov [Bulletin of Civil Engineers], 2 (61), pp. 205-213. DOI: 10.23968/1999-5571-2017-14-2-205-212. (in Russian)

Kurakina, E.V., Shimanova, A.A., Lyalinov, A.N. (2017). Sovershenstvovanie metodiki proektirovaniia vibroshnekovykh smesitelei [Improving the design technique of vibro-auger mixers]. Vestnik grazhdanskikh inzhenerov [Bulletin of Civil Engineers], 3 (62), pp. 200-206. DOI: 10.23968/1999-5571-2017-14-3-194-199. (in Russian)

Kurakina, E.V., Stepina, P.A., Druzhinin, V.M. (2017). Kompleksnaia mekhanizatciia zemlianykh rabot v usloviiakh otritcatelnykh temperatur [Complex mechanization of earthwork operations in conditions of subzero temperatures]. Vestnik grazhdanskikh inzhenerov [Bulletin of Civil Engineers], 4 (63), pp.182-187. DOI: 10.23968/1999-5571-2017-14-4-182-187. (in Russian)

Kurakina, E.V., Tsymbal L.V. (2017). Osobennosti ekspluatatcii vakuumno-vsasyvaiushchego ekskavatora pri proizvodstve rabot $\mathrm{v}$ usloviiakh nizkikh temperatur [Features of vacuum suction excavator operation at low temperatures]. In: Proceedings of the 70th All-Russian Scientific and Practical Conference of Students, PhD Students and Young Scientists "Challenging Issues of Modern Construction".

Ministry of Transport of the RF (2015). No. AM-23-r dd. 14.03.2008 (revision: 14.07.2015) "On implementation of guidelines "Consumption rates for fuels and lubricants in motor vehicles".

Repin, S.V., Chmil, V.P. (2012). Raschetnye modeli obespecheniia rabotosposobnosti i effektivnosti transportno-tekhnologicheskikh mashin $v$ ekspluatatcii [Calculation models to ensure the operating capability and efficiency of transport technological machines]. Saint Petersburg: Saint Petersburg State University of Architecture and Civil Engineering, p.89. (in Russian)

Volkov, S.A., Evtyukov, S.A. (2008). Stroitelnye mashiny [Construction machinery]. Saint Petersburg: Publishing House DNK, p.704. (in Russian) 